\title{
Micro ecosystems from feed industry surfaces: a survival and biofilm study of Salmonella versus host resident flora strains
}

\author{
Olivier Habimana ${ }^{1 *}$, Trond Møretrø ${ }^{1}$, Solveig Langsrud ${ }^{1}$, Lene K Vestby ${ }^{2}$, Live L Nesse², Even Heir ${ }^{1}$
}

\begin{abstract}
Background: The presence of Salmonella enterica serovars in feed ingredients, products and processing facilities is a well recognized problem worldwide. In Norwegian feed factories, strict control measures are implemented to avoid establishment and spreading of Salmonella throughout the processing chain. There is limited knowledge on the presence and survival of the resident microflora in feed production plants. Information on interactions between Salmonella and other bacteria in feed production plants and how they affect survival and biofilm formation of Salmonella is also limited. The aim of this study was to identify resident microbiota found in feed production environments, and to compare the survival of resident flora strains and Salmonella to stress factors typically found in feed processing environments. Moreover, the role of dominant resident flora strains in the biofilm development of Salmonella was determined.

Results: Surface microflora characterization from two feed productions plants, by means of $16 \mathrm{~S}$ rDNA sequencing, revealed a wide diversity of bacteria. Survival, disinfection and biofilm formation experiments were conducted on selected dominant resident flora strains and Salmonella. Results showed higher survival properties by resident flora isolates for desiccation, and disinfection compared to Salmonella isolates. Dual-species biofilms favored Salmonella growth compared to Salmonella in mono-species biofilms, with biovolume increases of 2.8-fold and 3.2-fold in the presence of Staphylococcus and Pseudomonas, respectively.

Conclusions: These results offer an overview of the microflora composition found in feed industry processing environments, their survival under relevant stresses and their potential effect on biofilm formation in the presence of Salmonella. Eliminating the establishment of resident flora isolates in feed industry surfaces is therefore of interest for impeding conditions for Salmonella colonization and growth on feed industry surfaces. In-depth investigations are still needed to determine whether resident flora has a definite role in the persistence of Salmonella in feed processing environments.
\end{abstract}

\section{Background}

Salmonella contaminations in animal feeds are important vectors for Salmonella infections in livestock farms [1-9]. The presence of Salmonella enterica serovars in feed ingredients is a well-known problem. Heat treatment of animal feed is central for ensuring microbial feed safety, despite the fact that some reports stated that thermal treatment conditions during pelleting are not effective for eliminating Salmonella contamination in feeds $[10,11]$. However, since most feed plants have good

\footnotetext{
* Correspondence: olivier.habimana@nofima.no

${ }^{1}$ Nofima Mat AS, Osloveien 1, N-1430 Ås, Norway

Full list of author information is available at the end of the article
}

control over heat treatment procedures, feed contamination is most likely due to recontamination from feed processing environments [12]. Despite strict safety measures implemented by the feed industry in Norway, certain Salmonella serovars (e.g. Agona, Montevideo and Senftenberg) are routinely isolated, and molecular typing data indicate that specific strains have persisted in certain feed processing environments for years [6].

The choice of disinfectants and proper cleaning practices are critical factors for eliminating Salmonella [2], yet the use of cleaning and disinfection is limited in feed processing environments, as a means to ensure dry production environments. The overall dry production

\section{(Ciomed Central}


environment in the feed production industry limits bacterial growth, including growth of Salmonella. However, on certain production surfaces, condensation caused by temperature variations may provide sufficient moisture to bacterial niches, in which Salmonella and other bacteria are likely to grow and form biofilms [13]. In addition, lack of cleaning may lead to a build-up of organic material as well as settlement and establishment of other microorganisms on feed processing surfaces $[13,14]$. Recent studies have shown that biofilm formation plays a role in the ability for Salmonella to survive and persist in feed and food processing environments [14-16]. The presence of such resident flora on feed processing surfaces could potentially promote microbial adhesion and subsequent biofilm formation and persistence of unwanted pathogenic bacteria. Studies have shown that the presence and type of resident biofilms on a surface could significantly influence the initial adhesion of Listeria monocytogenes and Escherichia coli O157:H7 and their subsequent surface colonization $[17,18]$. Furthermore, recent studies have revealed that $E$. coli $\mathrm{O} 157: \mathrm{H} 7$ biofilm formation abilities were increased by the presence of some beef processing resident flora isolates [18,19].

The persistence and epidemiology of Salmonella in feed factories is relatively well documented $[6,14,15,20,21]$. However, other bacteria in feed factories have been less investigated. There is no knowledge as to whether the composition of a resident bacterial flora affects the growth and survival of Salmonella in feed processing environments. An improved understanding of the microbial ecology of feed production facilities and their potential interactions with Salmonella would be important in order to introduce improved strategies to eliminate Salmonella in the feed industry. In this study, we characterized resident aerobic bacterial flora at four critical control points of two feed production plants using $16 \mathrm{~S}$ rDNA sequencing of bacterial isolates. Survival properties under different environmental conditions and susceptibility to disinfectants were examined for selected isolates. Furthermore, the effects of selected resident flora isolates on the biofilm formation of Salmonella were investigated.

\section{Methods}

\section{Bacterial strains and growth conditions}

Salmonella strains used in this study are listed in Table 1. Four strains representative of the serovars of Salmonella spp. dominating in Norwegian feed factories were chosen, as well as the laboratory strain Salmonella Typhimurium ATCC 14028.

The five Salmonella spp. strains were made rifampicin-resistant $\left(\mathrm{Rif}^{\mathrm{R}}\right)$ by sub culturing at $30^{\circ} \mathrm{C}$ in Tryptone Soy Broth (TSB; Oxoid, Hampshire, England) with increasing concentrations of rifampicin (Sigma-Aldrich,
Table 1 Bacterial isolates used in this study

\begin{tabular}{|c|c|}
\hline Bacterial strain & Origin/Reference \\
\hline S. Agona $71-3^{a, b}$ & $\mathrm{FF} ;[6]$ \\
\hline S. Agona $71-4^{a}$ & $\mathrm{FF} ;[14]$ \\
\hline S. Montevideo $1900^{a}$ & $\mathrm{FF} ;[6]$ \\
\hline S. Senftenberg $1702-1^{a}$ & $\mathrm{FF} ;[6]$ \\
\hline S. Typhimurium ATCC $14028^{a}$ & Chicken; control strain; ATCC \\
\hline Corynebacterium sp. $1^{a}$ & FF; This study \\
\hline Corynebacterium sp. $2^{\mathrm{a}}$ & FF; This study \\
\hline Staphylococcus piscifermentans $1^{\mathrm{a}, \mathrm{b}}$ & FF; This study \\
\hline Staphylococcus piscifermentans $2^{a}$ & FF; This study \\
\hline Staphylococcus saprophyticus ${ }^{a}$ & FF; This study \\
\hline Pantoea agglomerans $1^{\mathrm{a}, \mathrm{b}}$ & FF; This study \\
\hline Pantoea agglomerans $2^{\mathrm{a}}$ & FF; This study \\
\hline Pseudomonas sp. $1^{\mathrm{a}}{ }^{\mathrm{b}} \mathrm{b}$ & FF; This study \\
\hline Pseudomonas sp. $2^{\mathrm{a}}$ & FF; This study \\
\hline
\end{tabular}

a Strains used for survival experiment.

b Strains selected for biofilm experiment.

FF: Feed factory strain.

MO, USA), to $200 \mu \mathrm{g} / \mathrm{mL}$. Salmonella isolates were cultivated at $30^{\circ} \mathrm{C}$ in TSB broth and Tryptone Soy Agar (TSA; Oxoid, Hampshire, England), when required, rifampicin was added to a final concentration of 100 $\mu \mathrm{g} / \mathrm{mL}$. No differences in growth rates were observed between Rif ${ }^{\mathrm{R}}$ Salmonella strains and their Salmonella wild type counterparts. For microscopic observations the pGFP-uv plasmid (CLONTECH laboratories, Palo Alto, USA) was electroporated into $S$. Agona 71.3 competent cells as previously described [22]. Bacterial sampling in two factories producing fish feed (Plant A) and animal feed (Plant B) was performed at four routine sampling sites (two from the pre-heat-/raw ingredient region and two from the post-heat-/product region). Samples were obtained by combined scraping and surface swabbing of feed ingredients and feed contact surfaces. Swabs were added to $10 \mathrm{~mL}$ peptone water, mixed and $1 \mathrm{~mL}$ dilutions were then transferred to Petrifilm Aerobic plate counts (3 M, Skjetten, Norway). Total aerobic bacteria and lactic acid bacteria were isolated from Petrifilm Aerobic Count Plates and de Man, Rogosa, Sharpe agar (MRA), respectively, after $30^{\circ} \mathrm{C}$ incubation. For bacterial identification, each colony (up to $n=20$ ) within a sector of the Petrifilm was isolated. The isolates were grown to pure culture in tryptone soya agar (TSA, Oxoid) at $30^{\circ} \mathrm{C}$ and stored in TSB with $15 \%$ glycerol at $-80^{\circ} \mathrm{C}$. Identification of isolates was performed by $16 \mathrm{~S}$ rRNA gene sequencing of approximately $500 \mathrm{bp}$ PCR amplicons encompassing the V1 to V3 regions as previously described [23]. Sequence homologies were identified using Genbank BLAST [24]. Isolated resident bacteria used for survival and biofilm experiments are listed in table 1. 


\section{Survival experiments}

To obtain information on temperature and humidity conditions near sampling sites, logging devices (EL-USB-2, Lascar Electronics Ltd., Salisbury, UK) were placed in Plant A for automatic logging of temperatures and relative humidities $(\mathrm{RH})$ for an approximate seven day production period. Based on recorded data, two temperatures and humidity conditions were selected for studies of bacterial survival on stainless steel surfaces. As a model for dry conditions, $30^{\circ} \mathrm{C}$ and $35 \% \mathrm{RH}$ parameters were chosen, whereas the model used for humid conditions was fixed at $12^{\circ} \mathrm{C}$ and $85 \% \mathrm{RH}$. The experimental system used for studying bacterial survival was in accordance with the previous description [25]. Adjustment of RH levels was achieved by saturated potassium chloride and saturated potassium acetate solutions for $85 \% \mathrm{RH}$ and $35 \% \mathrm{RH}$ ambient conditions, respectively. Sealed boxes with $35 \%$ $\mathrm{RH}$ were placed in an incubator at $30^{\circ} \mathrm{C}$ for $1,7,14$ and 28 days and boxes with $85 \% \mathrm{RH}$ were placed at $12^{\circ} \mathrm{C}$ for the same time period. Sampling and determination of viable bacterial counts was performed as described [25] and the number of viable cells was determined by plating to TSAagar. The experiment was conducted in triplicate.

\section{Disinfection tests}

In all bactericidal tests, bacteria were exposed to the lowest recommended user-concentration of disinfectants in the presence of bovine serum albumin (BSA) $(0.3 \% \mathrm{w} / \mathrm{v})$ for $5 \mathrm{~min}$ at $20^{\circ} \mathrm{C}$. The disinfection test used in this study was based on the European surface test (EN 13697), and was performed as previously described [13]. Three disinfectants were selected for bactericidal testing (Table 2). The selection was partially based on disinfectants representing the different categories of disinfectants used in Norwegian feed factories, and partially on these being among the most effective disinfectants against Salmonella dried on stainless steel [13]. Dey/Engley neutralizing broth (Difco) was used for diluting and neutralizing the disinfectants after exposure. The neutralization procedure was validated with the inhibition of all disinfectants tested. The total number of viable cells was determined by plating on Luria Bertani agar (LBA (per litre); 10 g tryptone (Oxoid); 5 g yeast extract (Oxoid) and $15 \mathrm{~g}$ agar (Oxoid)) and incubation for 2 days at $30^{\circ} \mathrm{C}$.
The efficacy of each disinfectant was calculated as the difference between the log transformed number of living bacteria exposed to deionized water (control) and disinfectant. All bactericidal tests were performed three times on different days and with freshly prepared solutions. All strains were tested separately.

\section{Biofilm experiment}

The biofilm system setup used for this study was performed using a Drip Flow Biofilm Reactor (Biosurface Technologies Corp., Bozeman, MT; [26]), with some modifications. Overnight cultures of GFP-tagged $S$. Agona 71.3 were mixed (1:1) with overnight cultures composed of Staphylococcus piscifermentans, Pantoea agglomerans or Pseudomonas sp. isolates. Cells in mixed suspensions were washed twice in sterile saline water $(0.85 \% \mathrm{NaCl})$ after centrifugation at $13000 \mathrm{rpm}$ for $4 \mathrm{~min}$, and then diluted tenfold in physiological saline water, of which $10 \mathrm{~mL}$ was aseptically introduced to the sterile drip flow chambers, each containing a clean sterile cover glass slide. Cell mixtures were allowed to adhere to the cover glass slides for two hours at ambient temperature $\left(25^{\circ} \mathrm{C}\right)$, after which the chambers were drained and the reactor inclined at a $10^{\circ}$ angle. The flow of medium $(0.5 \mathrm{~mL} / \mathrm{min}, 1 / 10$-strength TSB) was then initiated by attaching the influent tubing and starting the Watson-Marlow $205 \mathrm{U}$ peristaltic pump (Watson-Marlow Ld., Falmouth, England). Biofilms were grown at $25^{\circ} \mathrm{C}$ for $48 \mathrm{~h}$, after which the drip flow reactor was positioned horizontally and the medium flow to the reactor stopped. Mono- and dual-species biofilm experiments were performed in three independent assays.

\section{Laser-scanning confocal microscopy (LSCM)}

Horizontal plane images of the biofilms were acquired using a Leica SP5 AOBS laser scanning confocal microscope (Leica Microsystems, Norway). Biofilms were stained with red fluorescent nucleic acid strain using SYTO 61 dye $(200 \mu \mathrm{L}, 1 \mu \mathrm{M}$, Molecular probes, Invitrogen). Cover slides with stained biofilms were immediately placed in petri dishes containing a wet paper cloth saturated with deionized water to avoid dehydration. Petri dishes were then covered with aluminum foil and the dye was left to react with nucleic acids for $30 \mathrm{~min}$ in the dark. LSCM allowed simultaneous $3 \mathrm{D}$ monitoring of

Table 2 Disinfectants used in this study

\begin{tabular}{|c|c|c|c|c|}
\hline Disinfectant & $\begin{array}{l}\text { User concentration* } \\
(\%)\end{array}$ & $\begin{array}{c}\text { Active } \\
\text { component }\end{array}$ & $\begin{array}{c}\text { Content** } \\
(\%)\end{array}$ & Reference \\
\hline Ethanol & 70 & Alcohol & 100 & Kemetyl Norge AS, Norway \\
\hline P3 AlcoDes & undiluted & Alcohol & 70 & EcoLab AS, Oslo, Norway \\
\hline Virkon S & 1 & $\begin{array}{l}\text { Peroxygen } \\
\text { Persulfate }\end{array}$ & $>30$ & Lilleborg AS, Oslo, Norway \\
\hline
\end{tabular}

* User-concentration recommended by manufacturers.

** Content (\%) according to label on undiluted product. 
GFP and SYTO 61. The excitation wavelength used for GFP was $488 \mathrm{~nm}$, and the emitted fluorescence was collected at 500-600 $\mathrm{nm}$. The SYTO 61 was excited at $633 \mathrm{~nm}$, and the emitted fluorescence was collected at 650-700 nm. Images were collected through a $63 \times$ Leica oil immersion objective (numeric aperture, 1.4) with a $\mathrm{z}$ step of $1 \mu \mathrm{m}$. The quantification (biovolume, $\mu \mathrm{m}^{3}$ ) of GFP-tagged $S$. Agona 71.3 cells in mono- and mixed-species biofilms was estimated using PHLIP [27], a Matlabbased image analysis program http://sourceforge.net/projects/phlip/.

\section{Statistical analysis}

Statistical significance of differences in disinfection efficacy between Salmonella strains was tested using ANOVA in MINITAB v15.1 (Minitab Inc., State College, PA, USA). The statistical significance of differences in disinfection efficacy between disinfectants (AlkoDes, $70 \%$ ethanol and Virkon) and species (bacteria from feed factories and five Salmonella strains) was tested using Fishers exact test (available at http://www.langsrud.com/fisher.htm). Efficient disinfection was defined as tests resulting in $>4 \log$ reduction, which is the required disinfection effect to pass the European surface test. Statistical significance of differences in survival between Gram positive, Gram negative and Salmonella strains was tested for data at 28 days exposure using ANOVA in Minitab v15.1. Statistically significant differences in biovolume quantities $\left(\mu^{3}\right)$ of $S$. Agona 71.3 in mono- and mixed-species biofilms were analyzed with Tukey's test for pair wise comparisons (Minitab). All tests were performed at $5 \%$ significance level.

\section{Results}

\section{Bacterial flora in Norwegian feed industry plants}

A high bacterial diversity was obtained at pre-heat treatment sites compared to post-heat treatment sites in both feed Plants A and B (Table 3). In Plant A (fish feed plant), Staphylococcus spp. and Bacillus spp. were the dominant genera at sampling points before heat treatment, representing $39 \%$ and $18 \%$, respectively, of the total isolated flora. In post-heat treatment sites, Staphylococcus was more dominant, comprising $74 \%$ of the total isolated strains. Some endospore-forming isolates such as Bacillus and Paenibacillus were also identified in preheat treatment sites of Plant A. Among the isolates identified in post-heat treatment zones, three bacterial genera were not found in pre-heat treatment zones, such as Corynebacterium - an innocuous environmental bacterium, Pediococcus - a lactic acid bacterium and Kytococcus, formerly belonging to the Micrococcus genus.

In Plant B (animal feed plant), samples from pre-heat treatment sites were dominated by Pantoea (33\%), Curtobacterium (14\%), Staphylococcus (11\%), and Pseudomonas
Table 3 Composition of the microbiota at pre- and postheat treatment sample sites in two feed industry plants (Plant A (fish feed) and Plant B (animal feed))

\begin{tabular}{|c|c|c|c|c|}
\hline \multirow[t]{2}{*}{ Bacterial genus } & \multicolumn{2}{|c|}{ Pre-heat treatment } & \multicolumn{2}{|c|}{ Post-heat treatment } \\
\hline & No. strains & $\%$ & No. strains & $\%$ \\
\hline \multicolumn{5}{|l|}{$\underline{\text { Plant A }}$} \\
\hline Staphylococcus & 30 & 39 & 43 & 74 \\
\hline Bacillus & 14 & 18 & 3 & 5 \\
\hline Curtobacterium & 3 & 4 & - & - \\
\hline Corynebacterium & - & - & 4 & 7 \\
\hline Paenibacillus & - & - & 3 & 5 \\
\hline Pediococcus & - & - & 3 & 5 \\
\hline Pantoea & 7 & 9 & - & - \\
\hline Psychrobacter & 4 & 5 & - & - \\
\hline $\begin{array}{l}\text { Other genera } \\
\quad(n=15)\end{array}$ & 19 & 25 & 2 & 3 \\
\hline Total & 77 & & 58 & \\
\hline \multicolumn{5}{|l|}{$\underline{\text { Plant B }}$} \\
\hline Bacillus & 2 & 4 & 19 & 31 \\
\hline Curtobacterium & 8 & 14 & 2 & 3 \\
\hline Paenibacillus & 1 & 2 & 24 & 39 \\
\hline Plantibacter & 4 & 7 & - & - \\
\hline Staphylococcus & 6 & 11 & 2 & 3 \\
\hline Pantoea & 19 & 33 & 7 & 11 \\
\hline Pseudomonas & 6 & 11 & 1 & 2 \\
\hline $\begin{array}{l}\text { Other genera } \\
\quad(n=13)\end{array}$ & 11 & 19 & 6 & 10 \\
\hline Total & 57 & & 61 & \\
\hline
\end{tabular}

(11\%) while the spore-forming Paenibacillus and Bacillus dominated at post-heat treatment sites, representing 39\% and $31 \%$ of the total isolated strains. Similar to Plant A, samples isolated from sites after heat treatment were dominated by spore-forming isolates such as Paenibacillus (37\%) and Bacillus (29\%). Strains belonging to the genera most frequently observed at sites before heat treatment, including Pantoea, Staphylococci and Pseudomonas, were also present at post-heat treatment sites, but at a lower frequency (Table 3).

\section{Survival abilities of resident flora and Salmonella at different environmental conditions}

The strains used in this study were divided into three groups, Gram positive strains, Gram negative strains, and Salmonella strains. Gram positive isolates included Staphylococcus $(n=3)$, Corynebacterium $(n=2)$, Gram negative isolates consisted of Pantoea $(n=2)$ and Pseudomonas $(n=2)$ while Salmonella included isolates of $S$. Agona $(n=2)$ and one isolate each of serovars Montevideo, Senftenberg and Typhimurium.

Bacterial survival of Salmonella and dominant Gram positive and Gram negative flora isolates on stainless 
steel were investigated under warm and dry conditions $\left(30^{\circ} \mathrm{C}, 35 \% \mathrm{RH}\right)$ (Figure $\left.1 \mathrm{~A}\right)$, and cold and humid conditions $\left(12^{\circ} \mathrm{C}, 85 \% \mathrm{RH}\right)$ for a period of 28 days (Figure $1 \mathrm{~B}$ ). Compared to resident Gram negative bacteria, resident flora Gram positive bacteria, Corynebacterium, and Staphylococcus strains expressed higher tolerance in dry $(p<$ $0.001)$ and humid conditions $(p=0.005)$. Gram positive bacteria also showed better survival than Salmonella strains under both dry $(p<0.001)$ and humid $(p=0.042)$ conditions. Under dry conditions, no significant differences in survival were observed on days 7,14 and 28 between Salmonella and other Gram negative strains $(p=0.157)$. On days 14 and 28 , Gram negative bacteria were better survivors in humid conditions, compared to Salmonella strains $(\mathrm{p}<0.001)$. Salmonella survival was better $(p<0.001)$ at tempered and dry conditions $\left(30^{\circ} \mathrm{C}\right.$, $35 \% \mathrm{RH})$ compared to cold and humid conditions $\left(12^{\circ} \mathrm{C}\right.$, $85 \% \mathrm{RH})$.

\section{Comparison of susceptibility to disinfectants between feed factory resident bacteria and Salmonella}

The efficiency of P3-Alcodes, 70\% ethanol and Virkon S was tested in triplicate against five Salmonella strains originally isolated from feed factories using the European
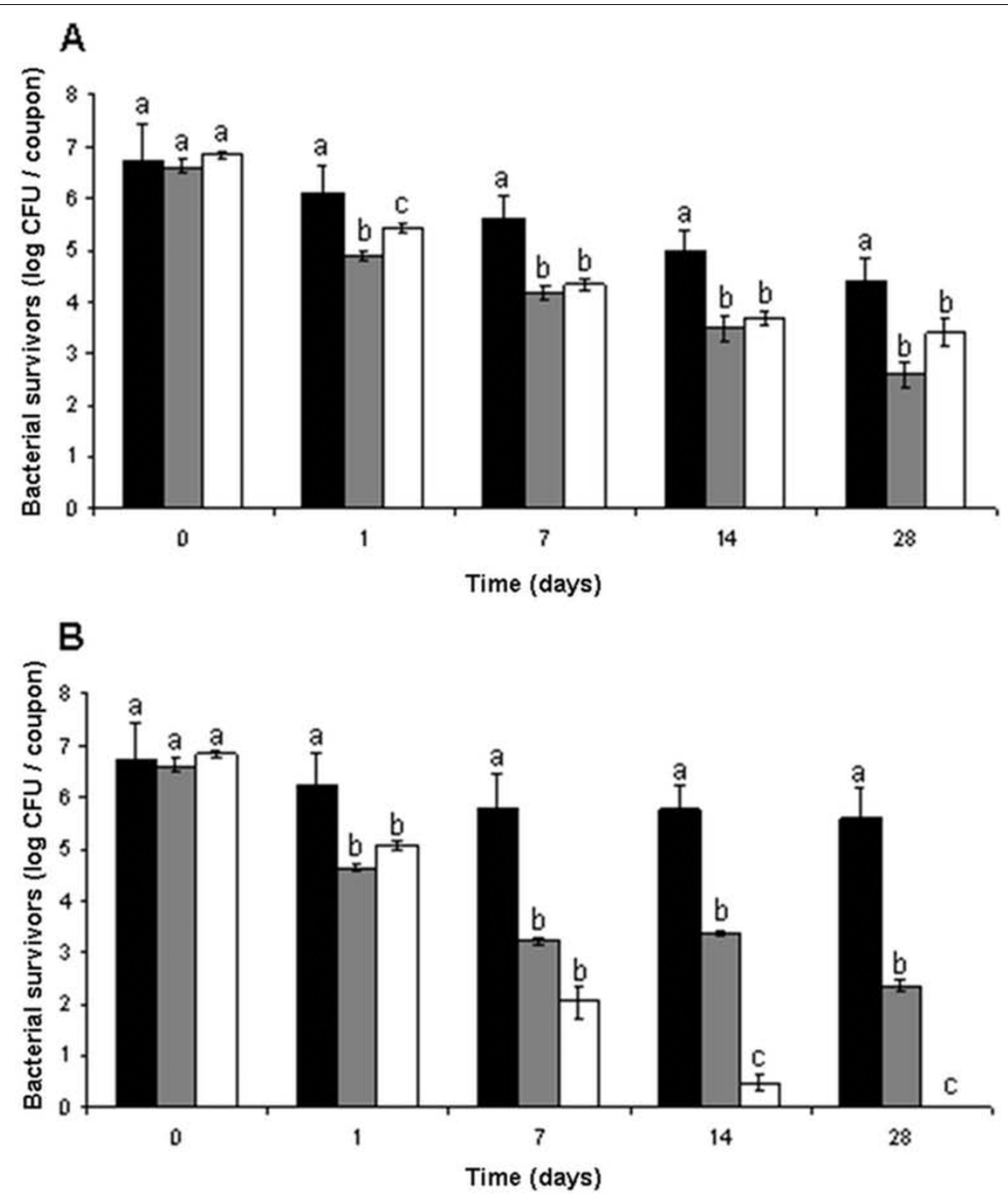

Figure 1 Bacterial survival of bacteria associated with feed industry at conditions A) $35 \% \mathrm{RH}$ and $30^{\circ} \mathrm{C}$; B) $85 \% \mathrm{RH}$ and $12^{\circ} \mathrm{C}$. Gram positives included Staphylococcus $(n=3)$, Corynebacterium $(n=2)$, Gram negatives included Pantoea $(n=2)$ and Pseudomonas $(n=2)$ while Salmonella included isolates of S. Agona $(n=2)$ and one isolate each of serovars Montevideo, Senftenberg and Typhimurium. Dark bars represent total tested Gram positive strains, gray bars depict Gram negatives, and white bars all tested Salmonella strains. Mean values of triplicate experiments are shown with error bars representing standard error of the mean. Within a group with the same incubation period $(0$ to 28 days; $x$-axis), mean values sharing at least one common letter are not significantly different at a $P$ value of $<0.05$. 
surface test. A total of 15 disinfection tests were performed for each disinfectant. For P3-Alcodes, 70\% ethanol and Virkon, $>4 \log$ reduction was obtained in 12, 10 and 10 of the disinfection tests, respectively (data not shown). No significant difference in efficiency was observed between the disinfectants used against Salmonella, or between Salmonella strains.

P3-Alcodes, 70\% ethanol and Virkon S were also tested against eight dominant resident flora isolates from two feed factories (Table 1). A total of 24 disinfection tests were carried out for each disinfectant. For P3Alcodes, 70\% ethanol and Virkon, $>4 \log$ reductions were obtained in 17, 10 and 6 of the disinfection tests, respectively (data not shown). P3-Alcodes was significantly more efficient than Virkon $S(p=0.0017)$ and $70 \%$ ethanol $(p=0.04)$. No significant differences in susceptibility between the strains were observed.

When comparing disinfection results, Salmonella strains were more sensitive to Virkon $\mathrm{S}$ than isolated resident flora strains $(p=0.034)$. When the effect of disinfectants was compared for all strains (Salmonella + resident flora), P3-Alcodes was significantly more efficient than Virkon $\mathrm{S}(p=0.02)$. No significant differences in disinfectant efficiency between P3-Alcodes and 70\% ethanol $(p=0.09)$, or between Virkon $\mathrm{S}$ and $70 \%$ ethanol $(p=0.33)$ were observed.

\section{Biofilms of resident flora isolates and their influence on Salmonella biofilm formation}

The influence of selected Staphylococcus piscifermentans, Pantoea agglomerans and Pseudomonas sp. resident flora isolates on the development of $S$. Agona 71-3 cells in mixed-species biofilms, was investigated. Figure 2 illustrates representative LCSM micrographs of mono- and multi-species biofilms of resident flora and GFP-tagged $S$. Agona after two days growth using the Drip Flow Biofilm Reactor. For observation and quantification, biofilms were stained with nucleic acid dye, SYTO 61. Different biofilm architectures were observed for mono-species biofilms composed of the selected Staphylococcus, Pantoea and Pseudomonas strains (Figure 2ABC). S. piscifermentans biofilms (Figure 2A) were defined as compact, with the presence of holes in its matrix. P. agglomerans biofilms were highly heterogeneous, featuring "mushroom-like" super structures, while Pseudomonas sp. (Figure 2C) formed homogenous hyperbiofilms, characterized by compacted cells with no presence of holes in its matrix. $S$. Agona mono-species biofilms (Figure 2D) were found to be composed of more channels than resident flora mono-species biofilms. In mixed-species biofilms, $S$. Agona cells (green) were found partially covering Staphylococcus microcolony niches (red), while showing an increased surface coverage $(p<0.001)$ when compared to $S$. Agona cells in mono-species biofilms (Figure 2DE). In the presence of Pantoea (Figure 2F), S. Agona cells (green) were found at the bottom of the biofilm, covered by Pantoea cells (red), which formed super structures on top of Salmonella cells. In the presence of Pseudomonas cells (Figure 2G), both S. Agona (yellow) and Pseudomonas cells (red) were found mixed together throughout the biofilm volume (orange).

Biofilm quantification analysis of mixed-species biofilms composed of $S$. Agona, revealed a 2.8-fold biovolume increase $(p<0.001)$ and 3.2-fold biovolume increase $(p<$ 0.001 ) for $S$. Agona cells in mixed-species biofilms of Staphylococcus and Pseudomonas, respectively, compared to $S$. Agona mono-species biofilms (Figure 3). No significant differences in biovolume $(p=0.6638)$ were observed for $S$. Agona cells in mono-species biofilms compared to mixed-species biofilms of Pantoea cells.

\section{Discussion}

While much attention is given to feed contamination by pathogenic strains in feed processing environments [6,28], there is little knowledge on the composition and survival of the environmental microbiota present throughout the feed production lines and its impact on the survival and persistence of Salmonella. We approached these questions by initially isolating and identifying the dominant, culturable microbiota in the two feed processing plants (one animal feed plant and one fish feed plant) followed by comparing the survival of selected resident flora strains and Salmonella strains to different disinfectants and environmental conditions. The impact of selected, dominant resident bacteria on the biofilm formation of Salmonella was also investigated.

The microbiota identified in pre-heat treatment sites from both animal and fish feed plants were mainly of environmental origins, most likely carried by incoming raw feed ingredients. Bacterial isolates belonged to genera commonly found in soil (Staphylococcus, Curtobacterium, Rathayibacter, Acinetobacter, Sanguibacter, Leucobacter), water (Pseudomonas, Psychrobacter, Rahnella, Stenotrophomonas, Rhodococcus), or included endosporeforming bacteria (Bacillus, Paenibacillus, Bacillaceae). Some of the isolated strains are known for being plant pathogens (Erwinia, Pantoea) or fish pathogens (Carnobacterium). Interestingly some common genera were isolated from both Plant A and B such as Paenibacillus, Bacillus, Staphylococcus and Pseudomonas. In Plant B, among the 10 genera identified on sites after heat treatment, six were also identified from sites located before heat treatment. This included strains within the genera Paenibacillus, Bacillus, Pantoea, Staphylococcus, Curtobacterium and Pseudomonas. For Plant A, strains within four (Staphylococcus, Pseudomonas, Bacillus and Paenibacillus) of the seven genera identified at sites after heat treatment were also found at sites before heat treatment. 


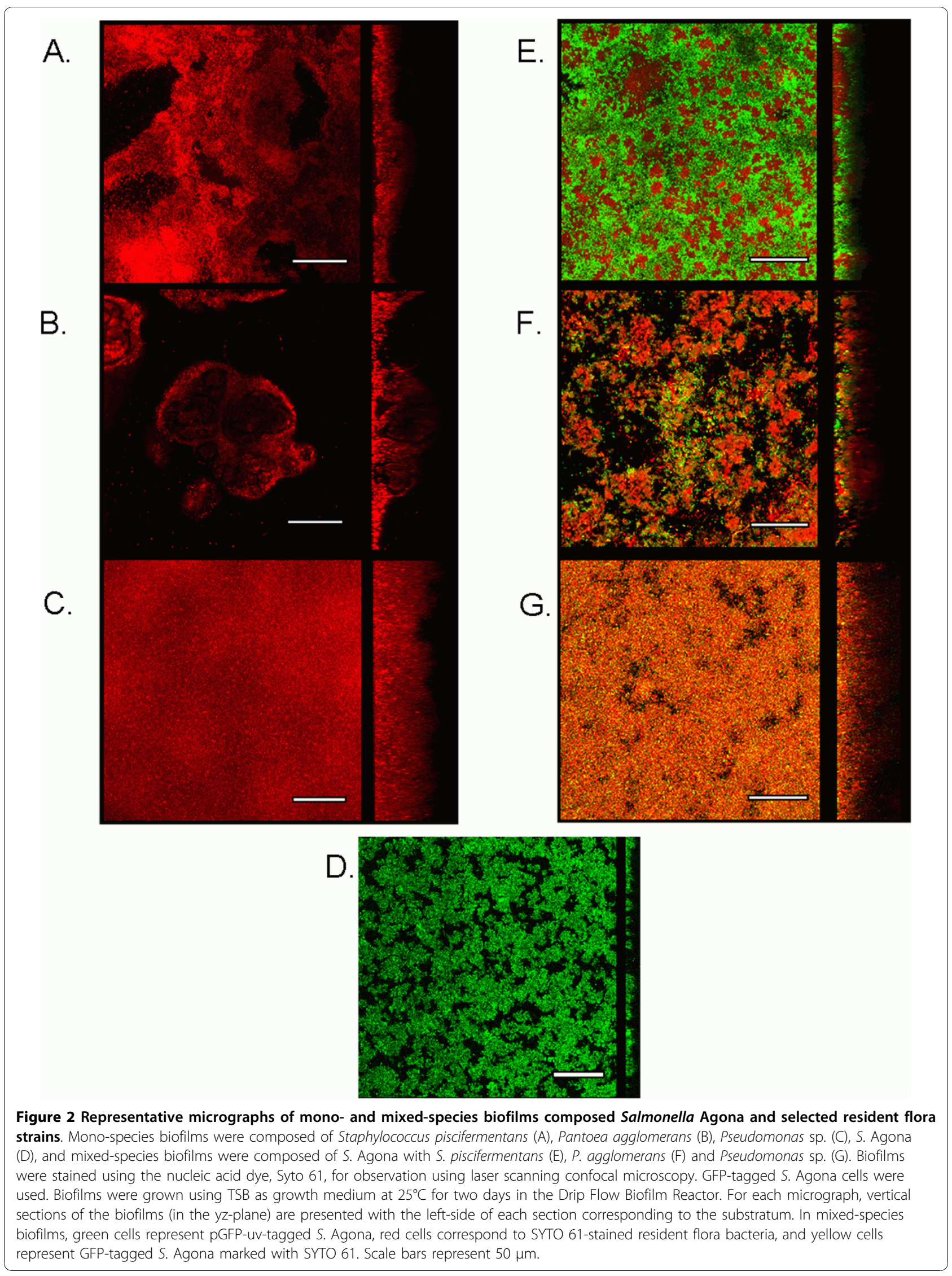




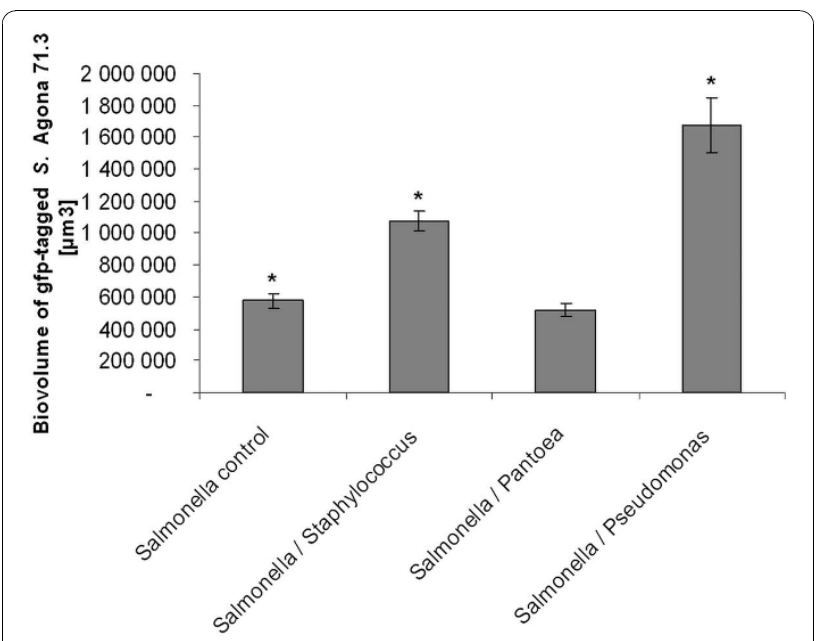

Figure 3 Biovolume quantification of Salmonella Agona in mono- and mixed-species biofilms. Biovolume was analyzed by PHLIP on S. Agona mono-species biofilms, and mixed-species biofilms composed of S. Agona with Staphylococcus piscifermentans, Pantoea agglomerans and Pseudomonas sp., after 2 days growth. Error bars indicate standard errors of mean values. Mean values sharing the symbol "*" are significantly different $(p<0.05)$.

The predominance of Staphylococci in post-heat treatment areas in the fish feed plant is indicative of their high tolerance to desiccation as demonstrated in previous studies [25,29]. Other studies have shown that Staphylococci adhere and form biofilms on a wide range of abiotic materials used in the food industry [30-32]. The lower diversity of genera observed at sites after heat treatment may indicate that certain strains have gained the ability to survive in defined feed production environments for long periods. The high presence of sporeforming strains within the genera Paenibacillus, Bacillus, Aneurinibacillus, Virgibacillus and Brevibacillus in postheat treatment sites are likely to be caused by their documented heat resistance [33-37]. Although the environmental conditions in the fish feed processing plant (Plant A) could be characterized as being more humid compared to the animal feed processing plant (Plant B), the hygienic conditions of both feed plants were found to be similar. Hygienic procedures in both Plants A and B are implemented to ensure Salmonella-free feed products. In both plants, these include mechanical removal of soil and dust by combined scraping, brushing and vacuum cleaning, followed by disinfection at specific critical control points. Data derived from hygiene testing are also used for the assessment of required sanitary measures at specific points. Although water may be used during cleaning processes at specific points of the production process, use of water is often avoided to maintain a dry environment. In this study, Plant A reported use of water for cleaning of the extruder while no water was applied in plant B in regular cleaning processes.

No Salmonella strains were isolated from animal or fish feed plants in this study. However, occurrences of Salmonella findings in the feed industry are relatively rare. When Salmonella is isolated, it is usually found in pre-heat treatment sites with raw ingredients as primary origin. The same has been reported from other studies $[4,9,38,39]$. Since logging of $\mathrm{RH}$ in the production plants showed differences in $\mathrm{RH}$ between plant $\mathrm{A}$ and $\mathrm{B}$, two relevant temperatures and $\mathrm{RH}$ conditions were selected for the surface survival studies. Although most of the Salmonella strains used in this study were presumed to have persisted in feed factories for years, resident flora strains survived better than all the Salmonella at in both humid and dry conditions over a period of 28 days. In general, survival and tolerance to desiccation were higher in Gram positive than Gram negative bacteria [40,41]. This has also been shown in other studies, for example a recent study where Staphylococcus simulans strains were more tolerant to desiccation compared to both $S$. Agona and $E$. coli strains [25]. Spore forming isolates were not selected in this study since the survival of spore-forming bacteria under the selected stress conditions is already well documented [42].

The uses of antimicrobial agents during cleaning and disinfection routines vary from one feed production plant to another. Although much focus is laid on the different types and specificity of antimicrobial agents currently in use by the feed industry, no study to our knowledge has investigated how resident flora isolates survive disinfection treatments. During this study, there were only small differences in disinfection efficiency against the different Salmonella strains, where ethanol based disinfectants and Virkon $S$ were found to be effective against tested Salmonella strains dried on stainless steel. There was also a tendency for these disinfectants to be more active against Salmonella than the dominating non spore-forming microbiota found in both fish feed and animal feed factories. Consequently, these results suggest that the use of ethanol based disinfectants or Virkon $S$ may reduce the Salmonella populations, while leaving the majority of the other bacterial populations less affected. In this study, Plant $A$ and Plant B applied different although commonly used feed industry disinfectants. Our observations showed variable efficacy of disinfectants on Salmonella and the resident bacterial flora (this study; [13]) Consequently the efficacy of commonly used disinfectants on the resident microflora is relevant, as the composition of the persistent environmental bacterial flora could promote survival and biofilm formation of Salmonella and other potential pathogens. The effect of various disinfectants 
on the resident bacterial flora in feed industry premises should be further addressed in future studies.

Salmonella is able to persist in feed factory environments for years [6]. One recent study showed that the persistence of Salmonella in feed environments was correlated to its ability to form biofilms [14]. Taking into account the corroborating survival and disinfection data obtained in this and previous studies [2,13], bacterial biofilm formation is a natural and most probably an important strategy of ensuring bacterial survival. Furthermore, the formation of condensation droplets resulting from temperature variations found in some areas (post-heat treatment) of feed processing lines, may enhance biofilm formation as previously suggested [13]. Indeed, the occurrence of such biofilm niches would most likely lead to microbial colonization of new areas of the production line $[43,44]$ and in worst cases, may become reservoirs for unwanted settled pathogenic bacteria [18]. Recent studies have reported that certain resident flora from food processing premises were able to either increase or decrease biofilm formation of Listeria monocytogenes [45,46] or E. coli $[18,19]$. However, it is not known whether the presence of a background flora in feed processing environments is beneficial or adverse to ensuing Salmonella colonization.

By using a biofilm growth model well suited for simulating conditions found in condensation environments, dominating non spore-forming resident flora isolates were found to be able to produce mature biofilms. Furthermore, beneficial effects were observed on the growth development of Salmonella in multispecies biofilms composed of either Staphylococcus or Pseudomonas. The presence of resident biofilms on feed processing surfaces could potentially facilitate the settlement and colonization of unwanted bacteria as demonstrated in previous studies $[17,18]$. Therefore, to ensure feed safety, measures should be implemented by the feed processing industry to eliminate potential biofilm forming resident flora together with specific unwanted flora.

In a preliminary experiment, potential antagonistic effects of the environmental background flora on Salmonella growth were also tested by agar overlay assays using BHI agar for growth of environmental bacteria overlaid with soft agar containing Salmonella (data not shown). Growth inhibition zones $(<3 \mathrm{~mm}$ diameter zones of inhibition) of $S$. Typhimurium were detected at a low frequency for only six out of approximately 4000 feed factory isolates. Thus, bacteria with significant antagonistic activity towards Salmonella seem not to be commonly present in feed industry environments.

It has been demonstrated in an earlier study that Salmonella cells could display a mutualism type of synergy in mixed community biofilms in the presence of Klebsiella pneumoniae [47]. Whether this type of synergism exists between feed processing Salmonella isolates in the presence of other resident flora isolates should be further investigated and could hold the key for better understanding the persistence properties of Salmonella strains in feed processing environments.

\section{Conclusions}

This study revealed that $(i)$ the survival of Salmonella is affected by conditions found in feed processing premises, with lower survival at a combination of low temperature and high humidity, (ii) resident bacterial isolates are good persisters and biofilm formers, (iii) commonly encountered resident bacteria as Pseudomonas and Staphylococcus may promote Salmonella biofilm formation in mixed-species biofilm cultivation; and (iv) commonly used disinfectants may differ in their bactericidal effect to various bacteria, affecting the potential biofilm formation of Salmonella. The presence of such mixed-species biofilms may potentially lead to colonization and persistence of Salmonella in feed production sites with subsequent pathogen contamination of feeds. The disinfectant efficacy of resident microflora is of relevance, as their effect may impact the biofilm formation and survival of Salmonella and other potential pathogens. Eliminating the establishment of resident flora isolates in feed industry surfaces is therefore of interest for impeding conditions that can lead to Salmonella colonization and growth on feed industry surfaces.

\section{Acknowledgements}

This study was supported by the Norwegian Research Council, Felleskjøpet Fôrutvikling BA, Norwegian Seafood Federation Fish-meal and -feed, Norgesfôr and NHO-Federation of Norwegian Meat Industry. We thank Liv Refvik for English revision. Birgitta Baardsen, Janina Berg, Anette Wold Åsli, Sigrun Storheim and Stina Lund Mustorp are greatly acknowledged for their technical assistance. We also thank the University of Life Sciences (UMB), Ås, Norway, for the microscope platform.

\section{Author details}

${ }^{1}$ Nofima Mat AS, Osloveien 1, N-1430 Ås, Norway. ${ }^{2}$ National Veterinary Institute, Section of Bacteriology, P.O. Box 750 Sentrum, N-0106 Oslo, Norway.

\section{Authors' contributions}

$\mathrm{OH}$ was responsible for the study design, the performing of experiments relating to long term survival, biofilm formation of Salmonella and host flora strains, the analysis of data from these experiments and the preparation of the manuscript. EH was responsible for the bacterial identification of strains isolated from feed processing surfaces. TM and SL were responsible for the susceptibility study of Salmonella and feed factory resident bacteria to disinfectants. LKV and LLN participated in all these parts. All authors contributed to the study design and revision of the draft manuscript. All authors have read, edited and approved the final manuscript.

Received: 13 August 2010 Accepted: 2 November 2010

Published: 2 November 2010

\section{References}

1. Davies RH, Wray C: Distribution of Salmonella contamination in ten animal feedmills. Vet Microbiol 1997, 57(2-3):159-169. 
2. Møretrø T, Midtgaard ES, Nesse LL, Langsrud S: Susceptibility of Salmonella isolated from fish feed factories to disinfectants and air-drying at surfaces. Vet Microbiol 2003, 94(3):207-217.

3. Shapcott RC: Practical aspects of Salmonella control. Progress report on a programme in a large broiler integration. In Proceedings of the international Symposium on Salmonella. Edited by: Snoeyenbos GH. Kennett Square, PA, USA: American Association of Avian Pathology; 1984:109-114.

4. Crump JA, Griffin PM, Angulo FJ: Bacterial contamination of animal feed and its relationship to human foodborne illness. Clin Infect Dis 2002, 35(7):859-865.

5. Davis MA, Hancock DD, Rice DH, Call DR, DiGiacomo R, Samadpour M, Besser TE: Feedstuffs as a vehicle of cattle exposure to Escherichia coli 0157:H7 and Salmonella enterica. Vet Microbiol 2003, 95(3):199-210.

6. Nesse LL, Nordby K, Heir E, Bergsjoe B, Vardund T, Nygaard H, Holstad G: Molecular analyses of Salmonella enterica isolates from fish feed factories and fish feed ingredients. Appl Environ Microbiol 2003, 69(2):1075-1081.

7. Nesse LL, Refsum T, Heir E, Nordby K, Vardund T, Holstad G: Molecular epidemiology of Salmonella spp. isolates from gulls, fish-meal factories, feed factories, animals and humans in Norway based on pulsed-field gel electrophoresis. Epidemiol Infect 2005, 133(1):53-58.

8. Dargatz DA, Strohmeyer RA, Morley PS, Hyatt DR, Salman MD: Characterization of Escherichia coli and Salmonella enterica from cattle feed ingredients. Foodborne Pathog Dis 2005, 2(4):341-347.

9. Davies PR, Scott Hurd H, Funk JA, Fedorka-Cray PJ, Jones FT: The role of contaminated feed in the epidemiology and control of Salmonella enterica in pork production. Foodborne Pathog Dis 2004, 1(4):202-215.

10. Hacking WC, Mitchell WR, Carlson HC: Salmonella investigation in an Ontario feed mill. Can J Comp Med 1978, 42(4):400-406.

11. Jones FT, Axtell RC, Rives DV, Scheideler SE, Tarver JFR, Walker RL, Wineland MJ: A survey of Salmonella contamination in modern broiler production. J Food Prot 1991, 54:502-507.

12. Maciorowski KG, Herrera P, Jones FT, Pillai SD, Ricke SC: Cultural and Immunological Detection Methods for Salmonella spp. in Animal Feeds A Review. Vet Res Commun 2006, 30(2):127-137.

13. Møretrø T, Vestby LK, Nesse LL, Storheim SE, Kotlarz K, Langsrud S: Evaluation of efficacy of disinfectants against Salmonella from the feed industry. J Appl Microbiol 2009, 106(3):1005-1012.

14. Vestby LK, Møretrø T, Langsrud S, Heir E, Nesse LL: Biofilm forming abilities of Salmonella are correlated with persistence in fish meal- and feed factories. BMC Vet Res 2009, 5:20.

15. Vestby LK, Møretrø T, Ballance S, Langsrud S, Nesse LL: Survival potential of wild type cellulose deficient Salmonella from the feed industry. BMC Vet Res 2009, 5(1):43.

16. Joseph B, Otta SK, Karunasagar I: Biofilm formation by Salmonella spp. on food contact surfaces and their sensitivity to sanitizers. Int I Food Microbiol 2001, 64(3):367-372.

17. Habimana O, Meyrand M, Meylheuc T, Kulakauskas S, Briandet R: Genetic features of resident biofilms determine attachment of Listeria monocytogenes. Appl Environ Microbiol 2009, 75(24):7814-7821.

18. Habimana O, Heir E, Langsrud S, Asli AW, Møretrø T: Enhanced surface colonization of Escherichia coli 0157:H7 in biofilms of an Acinetobacter calcoaceticus isolate from meat-processing environments. Appl Environ Microbiol 2010, 76(13):4557-4559.

19. Marouani-Gadri N, Augier G, Carpentier B: Characterization of bacterial strains isolated from a beef-processing plant following cleaning and disinfection - Influence of isolated strains on biofilm formation by Sakai and EDL 933 E. coli O157:H7. Int J Food Microbiol 2009, 133(1-2):62-67.

20. Boqvist S, Hansson I, Nord Bjerselius U, Hamilton C, Wahlstrom H, Noll B, Tysen E, Engvall A: Salmonella isolated from animals and feed production in Sweden between 1993 and 1997. Acta Vet Scand 2003, 44(3-4):181-197.

21. Sauli I, Danuser J, Geeraerd AH, Van Impe JF, Rufenacht J, Bissig-Choisat B, Wenk C, Stark KD: Estimating the probability and level of contamination with Salmonella of feed for finishing pigs produced in Switzerland-the impact of the production pathway. Int J Food Microbiol 2005, 100(13):289-310.

22. Hanahan D, Jessee J, Bloom FR: Plasmid transformation of Escherichia coli and other bacteria. Methods Enzymol 1991, 204:63-113.

23. Blackwood KS, Turenne CY, Harmsen D, Kabani AM: Reassessment of sequence-based targets for identification of bacillus species. J Clin Microbiol 2004, 42(4):1626-1630.
24. Altschul SF, Gish W, Miller W, Myers EW, Lipman DJ: Basic local alignment search tool. J Mol Biol 1990, 215(3):403-410.

25. Møretrø T, Heir E, Mo KR, Habimana O, Abdelgani A, Langsrud S: Factors affecting survival of Shigatoxin-producing Escherichia coli on abiotic surfaces. Int J Food Microbiol 2010, 138(1-2):71-77.

26. Stewart PS, Rayner J, Roe F, Rees WM: Biofilm penetration and disinfection efficacy of alkaline hypochlorite and chlorosulfamates. J Appl Microbiol 2001, 91(3):525-532.

27. Xavier JB, White DC, Almeida JS: Automated biofilm morphology quantification from confocal laser scanning microscopy imaging. Water Sci Technol 2003, 47(5):31-37.

28. Maciorowski KG, Herrera P, Kundinger MM, Ricke SC: Animal feed production and contamination by foodborne Salmonella. Journal of Consumer Protection and Food Safety 2006, 1:197-209.

29. Fuster-Valls N, Hernández-Herrero M, Marín-de-Mateo M, Rodríguez-Jerez JJ: Effect of different environmental conditions on the bacteria survival on stainless steel surfaces. Food Control 2008, 19:308-314.

30. Cucarella C, Solano C, Valle J, Amorena B, Lasa I, Penades JR: Bap, a Staphylococcus aureus surface protein involved in biofilm formation. $J$ Bacteriol 2001, 183(9):2888-2896.

31. Gross M, Cramton SE, Gotz F, Peschel A: Key role of teichoic acid net charge in Staphylococcus aureus colonization of artificial surfaces. Infect Immun 2001, 69(5):3423-3426.

32. Herrera JJ, Cabo ML, Gonzalez A, Pazos I, Pastoriza L: Adhesion and detachment kinetics of several strains of Staphylococcus aureus subsp. aureus under three different experimental conditions. Food Microbiol 2007, 24(6):585-591.

33. Mallidis CG, Scholefield J: Relation of the heat resistance of bacterial spores to chemical composition and structure. II. Relation to cortex and structure. J Appl Bacteriol 1987, 63(3):207-215.

34. Beaman TC, Gerhardt P: Heat resistance of bacterial spores correlated with protoplast dehydration, mineralization, and thermal adaptation. Appl Environ Microbiol 1986, 52(6):1242-1246.

35. Nakashio S, Gerhardt P: Protoplast dehydration correlated with heat resistance of bacterial spores. J Bacteriol 1985, 162(2):571-578.

36. Marquis RE, Bender GR: Mineralization and heat resistance of bacterial spores. J Bacteriol 1985, 161(2):789-791.

37. Soper $C J$, Davies DJ: The heat resistance of bacterial spores after different vacuum drying treatments. J Pharm Pharmacol 1971, 23:256S.

38. Jones FT, Richardson KE: Salmonella in commercially manufactured feeds. Poult Sci 2004, 83(3):384-391.

39. Whyte P, McGill K, Collins JD: A survey of the prevalence of Salmonella and other enteric pathogens in a commercial poultry feed mill. Journal of Food Safety 2004, 23(01):13-24.

40. Janning B, in 't Veld PH, Notermans S, Kramer J: Resistance of bacterial strains to dry conditions: use of anhydrous silica gel in a desiccation model system. J Appl Bacteriol 1994, 77(3):319-324.

41. Kramer A, Schwebke I, Kampf G: How long do nosocomial pathogens persist on inanimate surfaces? A systematic review. BMC Infect Dis 2006, 6:130.

42. Prescott L, Harley JP, Klein DA: Microbiology. Sixth edition. New York, NY: McGraw-Hill; 2004

43. Carpentier B, Cerf O: Biofilms and their consequences, with particular reference to hygiene in the food industry. J Appl Bacteriol 1993, 75(6):499-511.

44. Chmielewski RAN, Frank JF: Biofilm Formation and Control in Food Processing Facilities. Comprehensive Reviews in Food Science and Food Safety 2003, 2:22-32.

45. Leriche V, Chassaing D, Carpentier B: Behaviour of L. monocytogenes in an artificially made biofilm of a nisin-producing strain of Lactococcus lactis. Int J Food Microbiol 1999, 51(2-3):169-182.

46. Carpentier B, Chassaing D: Interactions in biofilms between Listeria monocytogenes and resident microorganisms from food industry premises. Int J Food Microbiol 2004, 97(2):111-122.

47. Jones K, Bradshaw SB: Synergism in biofilm formation between Salmonella enteritidis and a nitrogen-fixing strain of Klebsiella pneumoniae. J Appl Microbiol 1997, 82(5):663-668.

doi:10.1186/1746-6148-6-48

Cite this article as: Habimana et al:: Micro ecosystems from feed industry surfaces: a survival and biofilm study of Salmonella versus host resident flora strains. BMC Veterinary Research 2010 6:48. 